\title{
Attitude towards marriage, sexual adjustment and performance of married working women
}

\author{
SEEMA DEY AND JYOTIRMOY GHOSH
}

Received: 02.03.2016; Revised: 27.03.2016; Accepted: 12.04.2016

See end of the paper for authors' affiliations

\section{SEEMA DEY}

Post Graduate Department of Home

Science, Ranchi University,

RANCHI (JHARKHAND) INDIA

Email : seemadey@ rediffmail.com
ABSTRACT : Marriage is not a mere convention, but an implicit condition of human society. It is an adjustment between the biological purposes of nature and the sociological purposes of man. Its success only depends on the way it is worked. The present study was planned to investigate the attitude towards marriage, sexual adjustment and performance of working women from different organized sectors. A sample of 300 working women was selected purposively. Forty six per cent respondents were strongly agreed about registration of marriage. A substantially high proportion (58.7\%) of respondents strongly disagreed with the statement of having sexual relations without marriage. College teacher and clerk had more favorable attitude towards marriage. A small proportion of husbands and wives were unfaithful to their counterparts in sexual matters. Fifty-three per cent working women were able to manage their dual roles satisfactorily.

KEY WORDS: Working women, Attitude, Marriage, Sexual adjustment

— HOW TO CITE THIS PAPER : Dey, Seema and Ghosh, Jyotirmoy (2016). Attitude towards marriage, sexual adjustment and performance of married working women. Asian J. Home Sci., 11 (1) : 40-47, DOI: 10.15740/HAS/AJHS/11.1/40-47. 